\title{
Does Foreign Aid Make a Difference? A Critique from a Civil Society Organisation in Lesotho
}

\author{
Johnson Lineo \\ Dept. of ABET \& Youth Development, College of Education, University of South Africa \\ Email address: johnsIr@unisa.ac.za
}

\section{Doi:10.5901/mjss.2014.v5n20p1168}

\begin{abstract}
Lesotho is a country plagued by underdevelopment and poverty. This paper is a case study of an indigenous community organisation in the northern district of Botha-Bothe in Lesotho. Boseele is a rural development organisation which attracted international donor investment in the aftermath of the Lesotho Highlands Water Project. The study aims at investigating the impact of capacity development processes. In this paper it is understood and interpreted to refer to multi-level analysis of contributing complexities affecting non-formal community education. Education is a contributing factor in community development. Alan Rogers' developmental basic model to change interrogates the realities of empowerment theory against power dynamics and complexities, including foreign aid interventions in non-formal community education. A case study approach was used within a qualitative research design. Data were collected through individual and group interviews, observations, story-telling and transect walks. The results were analysed through thematic, chronological, narrative and document analysis. The study identified capacity-building landmarks over a period of ten years. Boseele's successes with Canadian International Development Agency (CIDA) funding reflect positive foreign aid contributions towards the work of civil society organisations in Lesotho, and the impact of community education and its multiplier effects. However, setbacks and lack of continuity by a nursery project funded by MS-Lesotho shows that the empowerment process is compromised where social and economic problems of individual members of civil society organisations and communities are not fully addressed. The funding intervention by the European Union posed challenges faced by short-term funding models for community education, its continuity and sustainability in particular and community development in general.
\end{abstract}

Keywords: capacity building; foreign donor interventions; community development; empowerment; power relations

\section{Introduction}

One of the main economic development projects in Lesotho from 1986 was the Lesotho Highlands Water Project (LHWP). This was a massive multi-billion rand dam construction and engineering project undertaken by Lesotho and South Africa. The project was inaugurated in 1986 by the governments of the two countries and was essentially meant to supply surplus water from Lesotho to South Africa and generate electricity. At its peak, the project employed about 5000 Basotho ${ }^{1}$. The project was located in the Thaba-Tseka and Botha-Bothe districts ${ }^{2}$. Upon completion of the construction, the project retrenched more than half of its employees and retained only those who would maintain subsequent operational phases of the Project. This is according to the Lesotho Highlands Water Project Report (2000).

This paper is a case study of a community-based organisation (CBO) called Boseele. The association is based in the Botha-Bothe district. The organisation was established and registered in 1997 by a group of concerned project and construction workers who were retrenched from the LHWP. The purpose of the organisation, according to the organisation's report (Boseele Association 2001) was to enable retrenched workers to address their household income needs through self-reliance, self-sufficiency and income-generating activities. These needs would be realised after the members undertook retraining programmes and capacity-building activities - some retrenched workers did not have skills, except those who were employed or trained to carry out duties by the LHWP. Most of the retrenched workers did not have the requisite skills to run income-generating projects.

Boseele is a Sesotho proverb shortened to mean: "The night has fallen (Bo-seele); one should wake up and work hard; a beggar cannot survive, but the heads of household should be able to provide for their families and become selfsufficient."

\footnotetext{
1 Lesotho is a country; Basotho are the people of Lesotho. The singular is Mosotho. The language is Sesotho.

${ }^{2}$ Lesotho has ten administrative districts. Katse Dam is found in the Thaba-Tseka district. 'Muela Hydropower Station in the Botha-Bothe district supplies the country with hydro-electricity.
} 
Boseele is a $\mathrm{CBO}$, and legally, an association. This study therefore makes reference to Boseele as a communitybased organisation, a non-governmental organisation (NGO), a non-state actor (NSA) and an association. Within the context of Lesotho, the four concepts are used interchangeably and they embrace civil society organisations or the civil society sector. Membership in Boseele ranges from highly qualified personnel to unskilled workers. The organisation initially registered about 150 men and women who joined as members from 1997 to 2000, according to the first audit report of the association of 2004 (Boseele Association 2004a). The organisation formed six activity clusters with different activities as follows: health centre facilities; home gardening and subsistence farming; poultry farming; piggery; tree and nursery plantation; and dairy farming (Boseele Association 1997).

Since the majority of the membership had funds in the form of retrenchment and fringe benefit packages, Boseele accumulated considerable funds from membership fees and was able to generate and yield substantive capital (Boseele Association 2001). The Association had funds which members could borrow and return their loans with low interest. It became a model NGO in the country which initially had self-generated resources, and where members benefited directly from their investments.

In 2000, three years later, the association established a health care centre called Boseele-Ha Motsoane Health Centre/Clinic. For three years, the health centre became the hallmark of Boseele's success. The health centre provided primary health care services to the surrounding communities. Through its financial resources, Boseele was able to provide necessary equipment for the health centre. However, health centres in many respects are basic social services which, even in developed countries, are subsidised by their governments. After running for three years, the health centre closed down due to lack of funds. There was no subsidy from the government, and handing over to the Lesotho government proved practically impossible, due to red tape, bureaucracy and lack of resources, despite its significant contribution in the neighbouring communities.

\section{Problem Statement}

In 2005, Boseele's successes reached their peak, while problems also started. The two donor partners, MS-Lesotho (previously known as the Danish Volunteer Services) and Canadian International Development Agency (CIDA), were impressed with the initiative by retrenched workers and arranged to fund the organisation. With international agencies come a lot of systems - programming, accounting, management, administrative, reporting and evaluative requirements. Too wide a range of activities were taking place in various locations. A huge membership created a lot of administrative and management work for executive members, the majority of whom were working as volunteers. The executive committee was composed of members from the three project sites. Within a decade Boseele had grown to an organisation with three big projects, donor support including technical consultants. At this point, one member recalled, "I felt like our organisation had grown bigger than we could handle as ordinary rural people, hence the foreigners 'invaded' our territory".

Some executive members were employed elsewhere and took up other responsibilities and could not continue to lead the organisation. Meetings meant to coordinate and oversee the progress of the three projects were no longer held and strategic and administrative decisions were not made because there was no quorum at executive meetings. Those who vacated their positions within the executive could not be replaced because the meetings lacked quorums to pass decisions. Non-executive members lost interest as they felt side-lined. Members defaulted on their membership payments, membership declined and a low level of activity prevailed, with projects left unattended, some with little or no supervision. Things seemed to be falling apart. The internal problems that emanated as the organisation grew could be well attributed to the new experiences it was encountering with foreign agencies as work and activities evolved and became demanding. According to one executive member, if it had resources of its own, it could have managed well with fewer problems. But because it needed donors' resources, there was tension and discord, as it had to learn how foreign agencies operated, thus importing knowledge and asset management approaches, which was a foreign concept.

Boseele was torn between two conflicting roles; the organisation was at a crossroads where it had to choose or balance how it handled donor infiltration and the "strings" as donations are often called. Is this easy to balance? This is the focus and the knowledge that this study intends to contribute. The assumption behind this is that civil society members join their organisations with indigenous knowledge and understanding of the community development they want to embark upon. However, when confronted with other foreign interventions such as funding requisites, they gain the knowledge which could be described as imported learning. The challenge, which the study investigated was how the two, foreign and indigenous knowledge, complement each other and how civil society members embraced the two worlds of knowledge. 


\section{Research Questions}

1) How has interaction with donor agencies contributed to capacity development and the knowledge base of Boseele's members?

2) Have internal problems experienced by Boseele been the result of donors' intervention or lack of knowledge and capacity building?

3) To what extent does foreign aid contribute in the life cycle of civil society organisations?

\section{Research Design}

This is a qualitative research study, and a case study method was used. A sample of 12 respondents was selected and purposive and convenience sampling techniques were used in identifying the respondents. Individual and group interviews, field observations, story-telling, documents and transect walk were used, with the interview guide and observation checklist prepared. Interviews were held with six (6) members of the Boseele civil society organisation who participated in different projects within a ten-year period. Since the study, as told by the Boseele members supported by available documents, had historical landmarks, it was easy to classify data into periodic content, thematic and narrative methods to analyse data. Themes and historical chronology of events facilitated easier coding of data into manageable units.

\section{Theoretical Framework}

Development is one of the most highly contested concepts, with many synonyms, expressions and semantics around it. This study was conducted within the ambit of the European Union (EU), and one of the mandates by the EU that was used for this study was the Cotonou Agreement (CA).

Rogers (1992:118) and Ferguson (1994:269) describe some of these deliberately planned and organised efforts as models or routes used in implementing and enhancing rural and community development programmes or projects. Rogers advises developers that there are critical stages essential to effective development and those steps form a model in which development becomes a long, winding process that requires patience, skills, time, commitment and desire to change. Models, which Rogers (1992:120) advises against in community development, are classified as bureaucratic, technocratic and direct-action routes. He adds that in these processes/models, "omitting or skipping the awareness and the knowledge/skills stages," in which actual capacity building evolves, results in "failure of projects." Where the critical stages of capacity building and ownership are skipped rural or community projects lack sustainability and often collapse due to these serious omissions.

\section{Findings}

In 2001, a few years after its legal registration as an association, Boseele had a membership of about 150 men and women around the country. Mr Oscar Maphuroane, the then chairperson recalled that Boseele's first bank savings amounted to about M50 $000^{3}$ derived from subscriptions and membership fees and donations from various local, national and international organisations. Boseele regarded its big membership as a success and an indication of how its vision was shared by many. However, experience had shown that having a large membership created challenges for a nonprofit making organisation. In 2010, the organisation had only 20 to 25 paid-up and active members. When it started, the subscription fee was M50. From 2009 it was increased to M200. Members are regarded as such only when they have paid their dues. The executive members have learned through experience that quality membership was what Boseele needed, not quantity. Its members now come from the Botha-Bothe district alone, not countrywide, as was the case when they started.

Maphuroane further emphasised that the strength or capacity of an organisation should not be judged or characterised by the number of members but the quality of service, commitment, participation, harmony and innovation they bring into the organisation. He also emphasised that civil society cannot survive without this important human resource which members bring into the sector. Similarly, civil society comprises individuals and membership organisations. The organisations survive because there are members who are neither employed nor paid but participate in development programmes meant to benefit themselves and their households, their organisations and their

\footnotetext{
${ }^{3}$ M50 000 is equivalent to ZAR50 000 - about US $\$ 10000$ at the time.
} 
communities at large. If these people deem it fit to spend their resources - time, knowledge, labour - and to share what they get for the benefit of other community members, there must be some reward or incentive that motivates them to remain and maintain their membership. The research findings in this study revealed some of the benefits and challenges as experienced by six members of Boseele.

\subsection{Mapheelle's health centre success}

Mr Lebohang Mapheelle hails from the southern district of Lesotho known as Quthing, but he was employed by the Lesotho Highlands Water Project (LHWP) for eight years working as an apprentice pharmacist in the LHWP's Leribe Trauma Unit/ Hospital. Mapheelle does not have an academic qualification in pharmacy, but his more than 30 years' experience in dispensing medicines from his former job in the mines and the LHWP placed him at an advantage. The LHWP continued to provide on-the-job training for him. He earned a substantial monthly income compared with most of the project employees.

Traditional healing is still highly regarded and hence Mapheelle has become a successful healer highly respected by his community. He took over the running, administration, resources and ownership of the centre. Other members were not happy with Mapheelle's inheritance of the organisation's resources. However, his argument was that the equipment was technical and would not benefit the organisation as only he had the expertise to use it. The equipment would become a "white elephant, benefiting nobody," he added. He continues to maintain the ethos of Boseele by being a successful farmer who owns many fields. He practices sharecropping with other community members, often his patients, particularly those who cannot afford to pay for health services. He speaks highly of his personal achievements and how Boseele has impacted on his success. He believes he would not have been successful if he had started alone. Boseele served as the platform for his success.

\subsection{Morena Peete's farming and leadership}

Morena Lira-ha-li-bonoe Peete hails from a royal and chieftaincy family, and is a headman ${ }^{4}$ of $\mathrm{Ha}$ Peete village, located within the 'Mate Ward. He is about 70 years of age. He was a founder member of Boseele and is the repository of "institutional memory" of Boseele as other members keep referring to him for the organisational history. He was a shopsteward in the LHWP and he seemed more informed and knowledgeable in many respects than other members of Boseele. During the interviews and in meetings, he seemed eloquent in the economic, political and environmental affairs of Lesotho and of other countries. Through his influence, Morena Peete was able to acquire the 'Mate nursery project site from his half-brother, chief of 'Mate.

Morena Peete believed that non-formal education geared to self-sufficiency could be productive in enhancing people's ability to become self-reliant. Young people should be encouraged to join in civil society programmes. He said this in the light of the deteriorating economic conditions of the Basotho. "Basotho should not rely anymore on political or economic leadership that promotes employment opportunities against self-sufficiency and self-reliance." He was convinced that the National University of Lesotho's motto, "taking the university to the people," should be more realised than it is currently. Formal Adult Education provided by the university is not enough; more non-formal training that addresses needs and aspirations for self-sufficiency should be promoted for the rural Basotho. He said young people should join civil society organisations because, "they are free learning institutions, if one is eager to learn". However, he also realised how difficult it was if young people had to be breadwinners in their lives and homes. He was concerned about the child-headed households' phenomenon, where small children lose parents and in turn become young parents themselves.

At the end of our interview, Peete said there are five attributes typical of the Basotho. "Basotho are not successful as civil society organisations' members because the majority of us are botsoa (lazy); (jealous); masholu (thieves); balotsana (cheats); and ba hloloa ke nako (poor time-keepers) (Interview June 2010).

\subsection{Boseele-'Mate Nursery Project (2000-2005)}

During 2000 to 2005, Boseele secured funding from the Danish Volunteer Service (DVS), later known as MS-Lesotho. The DVS-MS Lesotho funded the organisation to the tune of M350 000 (the equivalent of US\$50 000 then). It also provided technical support through one of its volunteers, Mr Clause Lackenhoff. According to the Project Design

\footnotetext{
${ }^{4}$ Headman is subordinate to a chief. Headmen either come from the chieftainship families or clans, or can be elected by village elders.
} 
Document (Boseele Association 2001), the main purpose of the project was to impart skills to the organisation's members while also generating funds for the sustainability of the organisation and its members' livelihood.

Khanare recalled, quoting the Danish Boseele-'Mate Nursery Project Document (Boseele Association 2001) that the Danish intention of providing technical support was to ensure that the local community and local government structures would take over the running and management of the project once the Danish had left. Capacity building was to be provided to the project members to enable a smooth transition and proper handover. The Boseele members were to be provided with technical and leadership skills to ensure continuity and sustainability of the project. The process was meant to empower the members and community to continue and claim ownership of the project. A series of capacity building and training activities were conducted for Boseele members through the MS-Lesotho funding and with other service providers and partners. 'Mamotaung Lesoetsa, the treasurer at Boseele-'Mate Nursery, said funding created new problems. "When members not employed in the nursery project started thinking others had more access to resources than they did, that created conflict, suspicion and mistrust," she said. Most of the people who criticised others were those who were idle and did not have much work. The project could not engage every member of Boseele. Those who knew little about the project created problems, confusion and conflict, and became a bad influence on others. 'Mamotaung said she experienced death threats at one stage, because some members who knew that she was the treasurer thought she and her family were benefiting from the project's resources, and that she was keeping money, resources and information from them.

On the other hand, 'Mamotaung showed us some wheelbarrows and garden tools which she herself confiscated from the project because she was still owed three months' wages, or rather stipend, when the MS-Lesotho funding came to an end. While she knew there were no more funds, she believed Boseele had funds which could have been used to pay her and four other employees. She said she was still bitter about her stipend, and she would not give back the wheelbarrows and garden tools to Boseele. As we walked along and towards the nursery project site, we saw beautifullybuilt gabions rehabilitating storm water. 'Mamotaung confirmed it was the result of their project development as the donga was growing bigger after every rainfall.

\subsection{Orphan and child-headed household challenges}

Thabelang Letho is a young man of 31 years who has just married. He is currently working as a street vendor in BothaBothe town, and originally comes from 'Mate Village where he was a member of the 'Mate nursery project. Thabelang said he did not volunteer his services in the nursery project. He had to work to earn a living for his brothers as well. He joined the nursery project purely as a means of employment and to get money for survival. He left when he realised the workers were not paid. When World Vision (WV) came into the area he attended their meetings. After realising that the organisation would pay school fees and other needs of his siblings he continued to participate in its activities. He then left Boseele to join World Vision in order to access the promised benefits and resources. Apart from the World Vision programme, Thabelang said he also joined the political ruling party and carried its card. "When development projects are brought into new areas, job opportunities are given first to card-carrying members," he revealed.

\subsection{Development interventions for immediate needs}

Nkhono (meaning "grandmother") 'Makhahliso Monkhoane is an old woman born in 1924, a widow who lives with her three grandchildren, all of whom are orphaned. Her son, daughter and daughter-in-law died of AIDS some four years ago, leaving three orphans in her care. She is old and does not have another source of income except the government grant for senior citizens. Her M1505 monthly grant is their only means of survival. She was a member of Boseele during the nursery project.

When World Vision came into the village, she joined its programme in search of assistance for her three orphaned grandchildren. "I became active with World Vision because I needed help and found it. Boseele failed me and I could not continue my membership. They used us. Why didn't they tell us that their organisation would only benefit young and able people?" She said she felt deceived and discriminated against, because of her age. In Lesotho, WV was established in 1976. It is known worldwide for its efforts to end hunger through different projects such as food aid and distribution, advocacy and pleading the cause of the hungry. WV is also internationally renowned for its child sponsorship programmes (retrieved on 25 July 2010 from http://www.worldvision.org/les. In Lesotho, WV states its commitment in partnering with the people of Lesotho individually and collectively to enhance their lives and to help enact sustainable

\footnotetext{
${ }^{5}$ M150/R150 - about \$21 a month (\$1/R10 rate)
} 
solutions for the future of their communities, families and children. Starting with only three projects, WV-Lesotho grew to 49 development projects clustered into area development projects (ADPs) around the country. 'Mate Village is within the Kota ADP. The Lesotho Child Sponsorship Programme cares for about 35249 Basotho children (retrieved on 25 July $2010 \mathrm{from}$ http://www.worldvision.org/les). It is therefore not surprising that the old lady and the young man found more fitting support from WV programmes than with the longer term empowerment project of Boseele. WV addressed immediate needs, such as food aid and school fees and was more relevant to them than Boseele. World Vision is applauded for its work with orphans and vulnerable children.

\section{Conclusions}

This section discusses the main issues raised by the three research questions, forms conclusions and suggests further research. The discussion points and conclusions are summarised into the themes below:

- $\quad$ Diverse environments and frameworks

- Empowerment of individuals through civil society programmes

- Capacity building interventions

- Power dynamics in development projects

- A critique: Does foreign aid make a difference?

\subsection{Diverse environments and frameworks}

Development programmes of civil society organisations should be evaluated within their legal, economic and social frameworks. The literature used for this paper and interviews concur that civil society organisations are established to enhance social benefits for communities. It is discovered that in Lesotho, economic benefits for volunteer members are critical and should be factored into any development project, particularly where civil society is seen as a development partner.

The literature review in this study pointed to the diverse environments in which civil society organisations work with limited technical resources. Diversities within development interventions demand that stakeholders talk to each other, particularly where they work with the same communities. Impact of donor interventions in development projects would be better realised and maximised if all stakeholders - governments, NGOs, local government, foreign agencies and communities - work together to ensure the success of community projects. Based on the Boseele's experiences, the study concludes that empowerment of communities is achievable and can lead to sustainable development and ownership of development projects. However, where stakeholders do not consult one another, development efforts may collapse, as was the case with the nursery project, where MS-Lesotho intervened/provided technical support.

\subsection{Empowerment of individuals}

Development projects do not succeed only because they are well designed and conceptualised. They are a result of effort, hard work, dedication and goodwill on the part of the individuals who plan them and those who implement them. Poor socio-economic conditions are a result of unfair distribution of a country's resources. However, not all poor people are willing to bring about change and improved social and economic conditions. There are sayings ("teach a person to fish rather than give him a fish" and "you can take a horse to water but you can't make it drink") that show that empowerment is impossible or cannot be realised when people do not make an effort and are not willing to participate.

The story of Mapheelle's health service provision illustrated an empowered individual whose bold decision making earned him good results and a small fortune. Morena Peete managed to climb the ladder through civil society organisations for his own benefits. He continued to benefit from the organisation because he was able to make personal sacrifices and worked hard so that he later earned an income while advancing projects for his organisation. Khanare and his team on the other hand, were not able to continue the nursery project. The project has remained an unused community liability while there were trained members who could continue benefiting from its operations. One wonders why they did not take the bold steps of resuscitating the project as Mapheelle did. Were they not empowered to do so? Their situations were similar and they could have easily continued producing seedlings and selling to their customers, but they did not. This shows that not all individuals act in the same manner, or are adequately empowered.

Communities will not sustain projects that are not beneficial to their social and economic needs. The issue of how immediate community needs should be addressed without compromising empowerment principles is critical. Incentives, 
handouts and social grants are an answer to this dilemma for as long as they lead to long-term sustainable development projects. This research confirms in no uncertain terms that if an individual is empowered economically, then empowerment within organisations can be realised through such individuals. If individuals are not empowered and economically motivated to undertake community work, empowerment and ownership of projects is compromised, since people have to deal with their own bread-and-butter issues first. The experiences of the nursery project therefore suggest that poor communities cannot sustain projects which do not generate an income for the individuals concerned and with no leadership to drive the decision-making initiative.

\subsection{Capacity development interventions}

At the beginning of each year when learners enter the classroom, the educator cannot always predict which learners will graduate at the end of the year. At the level of civil society, many join as members but few reach their full potential. Boseele has showcased this view. The study confirmed that capacity building as an aspect of adult education was provided in several forms - non-formal, continuing and informal educational modes and using flexible methods and techniques. Many capacity-building interventions were offered: skills development, information sessions, workshops, meetings, forums and workshops. These activities are presented at various levels by various agencies, according to their own goals and standards. Some individuals have benefited, but others did not.

\subsection{Power dynamics in development projects}

Empowerment is a result of many factors and reasons. Why some people are empowered and others are not, is not a matter of logic; people are not the same. Empowerment depends on various factors. If I was inclined to say men are more likely to be empowered than women, considering the two cases of Mapheelle and Peete, why then did Khanare (a male) feel incapacitated? In this case empowerment is not gender inclined, maybe more power based and influenced. The findings suggest that perhaps adult males like Mapheelle, Morena Peete and Khanare are better placed to take advantage of opportunities for empowerment because of their privileged position in Basotho society in relation to women and youth. Two women and a youth from the 'Mate nursery project, 'Mamotaung, 'Masamuele and Thabelang, respectively, had equal opportunities to benefit from the project but they never bothered to even think of themselves as owners or leaders of the project.

Would one also assume that empowerment has urban/rural divide and influence? Rural people felt incapacitated to take risks; why? Is the dependency syndrome more ingrained in rural areas than in urban areas or is this the result of urban/rural power dynamics in development projects? The two urban members - Mapheelle and Morena Peete - seemed to have taken bold decisions. Can one deduce from this that maybe urban people are exposed to a wider range of social relationships and role models than rural people? Khanare was not exposed to such networks and support structures. Do better-resourced people and those poorly resourced behave differently in participating and maintaining their participation in development projects? Rich/poor power dynamics and imbalances are at play. As a researcher and a writer, I can simply answer these questions based on my experiences and what the Boseele members said, but let us not forget that contexts for development are varied and responses to such are also diverse.

Donor prescriptions in the form of resources, authority, decision making on how projects should be run and whose knowledge base is more hegemonic than the other - these issues are not new to researchers. These are foreign/local power imbalances and yield power dynamics in development projects. This is a fact. The results of this study have been known for some time. They remain international, political, economic, dynamic and macro issues. They have direct implications for development projects. As long as adult educators are informed of these "beyond-us" dilemmas, and keep doing what they think is ethical and morally correct and just, social and economic injustices and inequalities in poverty, food insecurities and unemployment could be minimised or eliminated? These realities will never disappear. They forever remain part of us.

\section{A Critique: Does Foreign Aid Make a Difference?}

These discussions have brought us to the end of this study. The results have added more evidence in support of other previously written experiences reflected by the study. In response to the question, yes, foreign aid makes a difference, depending on how one looks at the development dynamics and emerging social and economic issues in society/societies. Foreign aid alone does not make social and economic needs disappear; foreign aid can stimulate change in communities that are also willing to benefit from it. Foreign aid is the result of other macro developmental, political and economic 
issues in society.

Another aspect of this study was how important an indigenous knowledge and participation in carrying out a social development agenda, which civil society organisations' members bring into community development projects, are. Often this important aspect is overlooked or taken for granted in the life cycle of organisations, yet it remains very valuable. While foreign funding contributes largely to the growth of the organisations in terms of assets and monetarily strengthening, Boseele's challenges faced in sustaining the nursery project showed that the two learning cultures - the indigenous and the imported, foreign cultures - should be harmonised. This is an important learning process for CSO members, who usually have to adjust in order to accommodate and augment their knowledge and dynamics with foreign agencies.

\section{Further Studies}

The findings of this study confirmed that perhaps an empirical study on the cultural beliefs, habits, values and aspirations of the Basotho could facilitate a better understanding of the Basotho's views on development projects and the work of civil society - a view that is also shared by Morena Peete, a traditional chief and trade unionist. Human capital theory is another aspect of this paper which was not discussed. It can be another topic on its own. The critique of foreign aid in developing countries has been debated for centuries. This will continue for as long as a top-down approach to development continues to be adopted by developed countries over developing ones. The debate continues.

\section{References}

Boseele Association. 1997. Constitution, amended in 2005. Maseru.

Boseele Association. 2001. Boseele-'Mate Nursery Project Document, memorandum of understanding. MS-Lesotho, Maseru.

Boseele Association. 2004a. Audit report 2000-2004. Maseru.

Boseele Association. 2004b. Boseele Agriculture and Share-Cropping Farming, memorandum of agreement. CIDA, Maseru.

Boseele Association. 2010. Boseele Animal Husbandry Project. European Union. LGNSP, Maseru.

Bureau of Statistics. 2006. National Census. Government of Lesotho, Maseru.

Ferguson, J. 1994. The anti-politics machine: "development," depoliticization and bureaucratic power in Lesotho. London: University of Minnesota Press.

Foreign Diplomatic/Consular Missions in Lesotho. Available at: http://www.foreign.lesotho.gov.ls (accessed on 15 January 2010).

Gastrow, S. 2010. Nonprofit sector provides sustainable solutions where business fails. Available at: http://www ngopulse.org/article (accessed on 30 June 2010).

Indabawa, S \& Mpofu, S. 2006. The social context of adult learning in Africa. Cape Town: Pearson Education.

Lesotho Highlands Water Project Report (2000), Volume 8, LHDA, Maseru.

Ministry of Local Government and Chieftainship. 2008. Strategic plan 2009-2013, Volume 1. GTZ, Maseru.

Rogers, A. 1992. Adults learning for development. London: Education for Development.

Webster, A. 1984. Introduction to the sociology of development. 2nd edition. London: MacMillan Education. (retrieved on 25 July 2010 from http://www.worldvision.org/les) 